\title{
Co-disposal Research of Red Mud and Aluminum Electrolysis Solid Waste Based on External Thermal Reduction and Smelting Separation
}

\section{En TANG ( $\nabla$ tangen@zjitc.edu.cn )}

Zhejiang Industry \& Trade Vocational College

Rui ZHANG

Zhejiang Industry \& Trade Vocational College

\section{Research Article}

Keywords: steel, red mud, waste cathode, anode toner, external heated reduction, smelting separation

Posted Date: July 14th, 2021

DOI: https://doi.org/10.21203/rs.3.rs-696247/v1

License: @) (1) This work is licensed under a Creative Commons Attribution 4.0 International License. Read Full License 


\section{Abstract}

In large aluminum smelting enterprises, the solid wastes of red mud and waste cathodes are satisfied the basic elements requirements of the solid-solid direct reduction technology. Thus, it is proposed a solution to use waste cathodes and red mud under indirect heating supply to produce pellets and to utilize in situ. It has been studied the reduction mechanism of red mud and waste cathode, the influence of carbon allocation method on pellet reduction and the research of the smelting separation and product quality. Experiment shows that the iron of red mud can be successfully reduced by waste cathode and anode toner at high temperature. The metallization rate of iron in red mud can reach more than $95 \%$ and the quality of pellets is more suitable with the mode of external carbon mixing. In order to carry out effective melting and separation of slag and iron, the red mud pellets must to be briquetted or to reserve a molten pool before charging into the melting furnace. After separation, the content of iron and carbon in steel can reach about $98.85 \%$ and $0.13 \%$ respectively, and the yield of iron elements can reach more than $96 \%$, the harmful components flow into the slag can be effectively solidified. Content of alumina in the slag reached about $37 \%$ which can be economically recycled to the alumina purification process as a matching.

\section{Background}

At present, a large amount of solid waste and hazardous waste are produced in large-scale aluminum smelting enterprises, among which the typical wastes are red mud produced in alumina production process and waste cathode and anode c5arbon powder produced in aluminum reduction cell during electrolytic aluminum process. About 70 million tons of red mud are produced every year in the world, among which about 30 million tons are produced every year in China. Many important advances have been achieved in the research of comprehensive utilization of red mud at home and abroad. But on the whole, current technology are still expensive, complex and uneconomic. Compared with the discharge capacity of red mud, current treatment capacity is quite small which the main reason that large-scale utilization of red mud has not been realized in the world so far. At present, about $95 \%$ of red mud is still disposed of by open storage ${ }^{[1]}$. Comprehensive utilization of red mud is still a worldwide and popular problem. With the progress of iron enrichment technology of red mud, the Fe content of iron concentrate enriched from red mud, which produced by the Bayer process, can reach more than $45 \%$. The concentrate can be used for iron and steel plants as ore blending to produce hot metal, but other elements, especially aluminum, have not been effectively utilized. It is still the main development direction of red mud to realize the reclamation, minimization and harmlessness to the maximum extent by means of recovering valuable metals and manufacturing civil materials ${ }^{[2]}$.

Solid wastes produced from aluminum cells, such as waste cathode and anode toner, contain a large amount of hazardous electrolyte components, among them there is quantities of soluble fluoride and cyanide. It is difficult to deal with, poor economy, the utilization value is low, At present, only a small amount of fluoride is recover for electrolyte extraction or carbon in spent cathode is used as fuel, A large number of waste cathodes are still treated mainly by landfill and stockpiling, The soluble fluoride and cyanide contained in it will be transferred or volatilized into the atmosphere by wind, sun and rain, or mixed with rainwater into rivers, linking people underground to pollute soil and groundwater, causing great damage to animals and human body, destroying the ecological environment, affecting the agricultural ecological balance, and reducing crop production. If harmless treatment is not carried out in time, the harm will be long-term ${ }^{[3]}$.

At present, factories are facing great pressure of environmental protection from the Chinese government, which has begun to levy environmental protection tax on solid waste treatment. This article intended to use external heating solid-solid direct reduction technology, that is iron oxide in red mud is reduced by carbon in waste cathode and anode toner to get iron and fluoride in waste cathode can be volatilized and then recycled in flue gas. Therefore, high metallization pellets of red mud and non-toxic cathode and anode toner are obtained. Pellets can melt iron elements into molten iron through melting separation, and high melting point oxides such as aluminum elements in the pellets are enriched into the slag to obtain high aluminum slag, i.e. "External heating synergistic reduction + melting separation", thus enabling red mud to be efficiently utilized ${ }^{[4]}$.

\section{Raw Material}




\section{1) Red mud powder}

In this experiment, Guinea bauxite (TFe= 25\%) imported from a domestic aluminum-making enterprise was used, and a large amount of red mud (TFe>30\%) containing iron oxide was produced by the Bayer process after alumina was prepared. Red mud can enrich iron elements through preliminary step magnetic separation to obtain red mud refined powder, whose total iron grade can reach more than $45 \%$. The main components and compositions are shown in Table 1\&2:

Table 1

Typical Components of Red Mud Refined Powder (wt \%)

\begin{tabular}{|cccccccccccc|}
\hline $\mathrm{SN}$ & $\mathrm{TFe}$ & $\mathrm{CaO}$ & $\mathrm{MgO}$ & $\mathrm{SiO}_{2}$ & $\mathrm{Al}_{2} \mathrm{O}_{3}$ & $\mathrm{~S}$ & $\mathrm{P}$ & $\mathrm{K}_{2} \mathrm{O}$ & $\mathrm{Na}_{2} \mathrm{O}$ & $\mathrm{TiO}_{2}$ & Others \\
\hline $1 \#$ & 47.17 & 0.53 & 0.17 & 2.9 & 11.48 & 0.02 & 0.1 & 0.03 & 1.18 & 6.1 & 10.1 \\
$2 \#$ & 46.67 & 0.62 & 0.12 & 3.06 & 11.43 & 0.05 & 0.1 & 0.03 & 1.13 & 5.9 & 11.1 \\
\hline
\end{tabular}

Table 2

Mineral Phase Analysis of Red Mud Fine Powder (wt \%)

\begin{tabular}{|c|c|c|c|c|c|c|c|c|}
\hline Item & $\begin{array}{l}\text { Sodium silicon } \\
\text { slag } \\
1.08 \mathrm{Na}_{2} \mathrm{O} * \mathrm{Al}_{2} \mathrm{O}_{3} \\
* 1.68 \mathrm{SiO}_{2} * 1.8 \mathrm{H}_{2} \mathrm{O}\end{array}$ & $\begin{array}{l}\text { Gibbsite } \\
\mathrm{Al}(\mathrm{OH})_{3}\end{array}$ & $\begin{array}{l}\text { Boehmite } \\
\text { monohydrate } \\
\text { AIO }(\mathrm{OH})\end{array}$ & $\begin{array}{l}\text { Quartz } \\
\mathrm{SiO}_{2}\end{array}$ & $\begin{array}{l}\text { Aluminium } \\
\text { goethite } \\
\mathrm{Fe} 0 . \\
8 \mathrm{Al}_{0.2} \mathrm{O}(\mathrm{OH})\end{array}$ & $\begin{array}{l}\text { Hematite } \\
\mathrm{Fe}_{2} \mathrm{O}_{3}\end{array}$ & $\begin{array}{l}\text { Anatase } \\
\mathrm{TiO}_{2}\end{array}$ & $\begin{array}{l}\text { Ilmenite } \\
\mathrm{FeTiO}_{3}\end{array}$ \\
\hline Percentage & 5.4 & 16.3 & 0.8 & 2.8 & 24.9 & 41.7 & 2.4 & 5.7 \\
\hline
\end{tabular}

According to Table $1 \& 2,60 \%$ of the iron in the red mud iron concentrate exists in the form of hematite, $33 \%$ is a eutectic compound formed by $\mathrm{Fe}_{2} \mathrm{O}_{3}$ and $\mathrm{Al}_{2} \mathrm{O}_{3}$, and the remaining $7 \%$ is mainly an eutectic compound formed by $\mathrm{Fe}_{2} \mathrm{O}_{3}$ and $\mathrm{TiO}_{2}$. Both iron and aluminum have certain recycling value.

\section{2) Waste cathode and anode carbon powder}

As the key equipment in the process of preparing aluminum ingots, when the lining of the aluminum reduction cell is damaged or replaced regularly, a large amount of waste cathodes immersed in the electrolyte will be generated. The main components are shown in Table 3:

Table 3

Main Components of Waste Cathode (wt \%)

\begin{tabular}{|llllllllllll|}
\hline Item & $\mathrm{C}$ & $\mathrm{Si}$ & $\mathrm{Al}$ & $\mathrm{Ca}$ & $\mathrm{Mg}$ & $\mathrm{Fe}$ & $\mathrm{Na}$ & $\mathrm{Ti}$ & $\mathrm{K}$ & $\mathrm{S}$ & $\mathrm{P}$ \\
Waste cathode & 59.16 & 0.69 & 4.76 & 16.70 & 0.25 & 10.43 & 1.94 & 0.37 & 1.86 & 0.92 & 1.22 \\
\hline
\end{tabular}

During the use of the electrolytic cell, not only the waste cathode will be generated, but also a lot of anode carbon powder will be generated due to carbon particle shedding caused by uneven combustion of carbon anode (Table 4), and the amount of anode carbon powder generated can reach $40 \sim 50 \%$ of the waste cathode amount. 
Table 4

Main Components of Anode Carbon Powder (wt \%)

\begin{tabular}{|llllll|}
\hline Moisture & Ash content & Fixed carbon & Total sulfur & Volatile matter & Low calorific value, KJ \\
\hline 22.77 & 33.37 & 65.16 & 1.68 & 2.15 & 16.35 \\
\hline
\end{tabular}

\section{3) Limestone}

Limestone was used to remove the sulfur from the raw material and Table 5 showed its composition as follows:

Table 5

Composition of Limestone (wt \%)

\begin{tabular}{|lllll|}
\hline Item & $\mathrm{CaO}, \%$ & $\mathrm{MgO}, \%$ & $\mathrm{SiO}_{2}+\mathrm{Al}_{2} \mathrm{O}_{3}, \%$ & Particle size, $\mathrm{mm}$ \\
\hline Quantity & $\geq 50$ & $<4$ & $\leq 3$ & $1 \sim 3$ \\
\hline
\end{tabular}

\section{Experimental Route}

Solid-solid direct reduction technology is a process in which metal oxides are reduced to form elemental metal by using carbon elements in the solid reducing agents. Heating methods in the reduction process are generally divided into direct internal heating by open flame and indirect external heating by isolated the flame. Heat transfer speed of internal heating is fast but the reduction atmosphere control is poor, while the external heating is slow but the reduction atmosphere is controllable and the product quality is better. Thus, the external heating method was selected in this paper. The specific implementation process is shows in Figure 1: The red mud powder was briquetting into green balls with additives, which were further mixed with waste cathode and anode carbon powder. Under the condition of external heating (Figure 2), heat is provided. After being heated to a certain temperature and kept for a time, the red mud pellets are reduced to metalized pellets with high metallization rate. Then the pellets and residual carbon materials were cooled and separated, the pellets were briquetted and charged into the electric furnace in order to separate the iron and aluminum. Based upon above process, finally the solid wastes were comprehensively utilized through the cooperative disposal.

According to the analysis in above and take the thermodynamic point into account, the experimental parameters are set with high temperature direct reduction method (Table 6).

Table 6

Batching Ratio and Experimental Parameters (wt \%)

\begin{tabular}{|llllllll|}
\hline $\begin{array}{l}\text { Sample } \\
\text { Number }\end{array}$ & $\begin{array}{l}\text { Green } \\
\text { ball }\end{array}$ & $\begin{array}{l}\text { Waste } \\
\text { cathode }\end{array}$ & $\begin{array}{l}\text { Anode carbon } \\
\text { powder }\end{array}$ & Limestone & $\begin{array}{l}\text { Reduction } \\
\text { temperature, }{ }^{\circ} \mathrm{C}\end{array}$ & $\begin{array}{l}\text { Restore } \\
\text { time, } \mathrm{h}\end{array}$ & \begin{tabular}{l} 
Comments \\
\hline C1
\end{tabular} \\
\hline 80: 20 & 60 & $/$ & 10 & 1180 & 12 & $\begin{array}{l}\text { Internal } \\
\text { carbon }\end{array}$ \\
\hline W1 & 100 & 40 & 20 & 10 & 1180 & 12 & $\begin{array}{l}\text { External } \\
\text { carbon }\end{array}$ \\
\hline
\end{tabular}

The chemical composition of red mud pellets with high metallization rate obtained from the experiment is shown in Table 7. 


\begin{tabular}{|lccccc|}
\hline Sample Number & TFe & MFe & MD ${ }^{1)}$ & S & C \\
\hline C1 & 55.04 & 53.83 & 97.80 & 0.2660 & 8.80 \\
\hline W1 & 58.28 & 55.53 & 95.28 & 0.0210 & 0.89 \\
\hline 1) MD=MFe/TFe, MD-metallization rate, MFe-metallic iron. \\
\hline
\end{tabular}

\section{Results And Discussion}

\subsection{Reduction Mechanism}

In Table 7, it can be seen that the reduction effect of iron oxide in pellets was better and the reduction rate was reached more than $95 \%$. The main mineral components in red mud are goethite, hematite, gibbsite, kaolinite, colloidal silica, quartz, diaspora and so on. During the reduction process, the reduced materials can be regarded as a system composed of monomer oxides such as $\mathrm{Fe}_{2} \mathrm{O}_{3}, \mathrm{A1}_{2} \mathrm{O}_{3}$ and $\mathrm{SiO}_{2}$. In the reduction process of these materials, not only the reduction phase transition of ironcontaining oxides, but also solid-state reaction among oxides. In the reduction process, the main reactions between carbon and iron oxides in waste cathode and anode carbon powder are as follows ${ }^{[5]}$.

$$
\begin{aligned}
& 3 \mathrm{Fe}_{2} \mathrm{O}_{3}+\mathrm{C}=2 \mathrm{Fe}_{3} \mathrm{O}_{4}+\mathrm{CO} \\
& \mathrm{Fe}_{3} \mathrm{O}_{4}+\mathrm{C}=3 \mathrm{FeO}+\mathrm{CO} \\
& \mathrm{FeO}+\mathrm{C}=\mathrm{Fe}+\mathrm{CO} \\
& 3 \mathrm{Fe}_{2} \mathrm{O}_{3}+\mathrm{CO}=2 \mathrm{Fe}_{3} \mathrm{O}_{4}+\mathrm{CO}_{2} \\
& \mathrm{Fe}_{3} \mathrm{O}_{4}+\mathrm{CO}=3 \mathrm{FeO}+\mathrm{CO}_{2} \\
& \mathrm{FeO}+\mathrm{CO}=\mathrm{Fe}+\mathrm{CO}_{2} \\
& \mathrm{FeTiO} \\
& \mathrm{C}+\mathrm{CO}=\mathrm{Fe}+\mathrm{CiO}_{2}+\mathrm{CO}_{2}=2 \mathrm{CO}
\end{aligned}
$$

Waste cathode and anode carbon powder were used as reducing agents, and carbon gasification reaction (8) would occur if the carbon amount was excessive. Therefore, the direct reduction of iron oxide was carried out with the participation of CO. During the whole reaction, the solid-solid reaction (1) (3) between green balls and reducing agent was quite small, while the reaction mostly was gas-solid reaction $(4) \sim(7)$, that is, the reducing agent first occurred oxidation reaction to generate $\mathrm{CO}$, which reacted with iron oxide. Finally, the equilibrium control of reduction atmosphere was realized through disproportionation reaction (8). Compounds such as calcium-iron olivine and iron spinel were generated during the reduction process. These compounds could form a series of low-melting mixtures, which would make the reduction process more complicated and difficult. It has been proved that adopting a high reduction temperature of $1180^{\circ} \mathrm{C}$ was beneficial to the reduction.

The total iron content in the reduced pellets reached about 55 58\% which was about $47 \%$ in the raw materials. The metallization rate is above $95 \%$ (Figure 3 ), that is, almost all iron were reduced. According to the weight balance, it showed that only the iron oxide has been reduced to metallic iron. All the results showed that the reduction effect was ideal. The other components in red mud and waste cathode were relatively stable even at high temperature. There was no vapor volatilization, which further verified the rationality and stability of the cooperative treatment of red mud, waste cathode and anode carbon by pyrometallurgy. The technical route is suitable for the treatment of hazardous wastes, such as waste cathode and anode carbon powder, which contains fluoride and other harmful substances ${ }^{[8]}$. 


\subsection{Blending Method of Carbon}

The reduction effect showed that waste cathode and anode carbon powder can be directly used as reducing agent at high temperature. Carbon plays the main role of reducing and has good reactivity at high temperature ${ }^{[6]}$, which was beneficial to the reduction of iron oxides. The content of $C$ and $S$ in the green ball has a great influence on the quality of subsequent products. Fig.3 showed the comparison of the content of $\mathrm{C}$ and $\mathrm{S}$ after reduction of different carbon blending method.

The internal carbon blending was one kind of green ball made by directly blending red mud with anode carbon with a weight charging ratio of $20 \%$. Fig. 4 showed after reduction the contents of $\mathrm{C}$ and $\mathrm{S}$ were $8.8 \%$ and $0.89 \%$ respectively, corresponding to external blending, which blending red mud ball with anode carbon were $0.266 \%$ and $0.021 \%$ respectively. The content of $C$ and $S$ in the metalized pellets was quite different that internal blending was about 40 times higher than external blending.

In the internal blending sample, it showed that anode carbon powder was directly added to the pellet and was the main reason which caused the higher of sulfur content. Since petroleum coke were the main raw material for producing cathode and anode carbon brick, which were basically treating at a high temperature of $1200^{\circ} \mathrm{C}$. Thus, in the cathode and anode most of the residue inorganic sulfur were stable and would not volatilize and affect the product quality. After undergoing high temperature reduction, sulfur still stayed in the metallized pellets. So the quality of the internal blending carbon pellets was badly affected the cost of the subsequent process.

However, for the external blending, due to the natural physical space isolation, sulfur was still remained in a separate reducing agent, so the $\mathrm{S}$ content in the metallized pellets affected by the carbon blending method was relatively low, which did not affect the use by the subsequent process. This also showed that the sulfur in all raw materials was mainly inorganic sulfur, which has been solidified in the raw materials, i.e., there was unnecessary to add desulfurizer for gas desulfurization.

In addition, although the metallization rate of internal blending was relatively higher, it was badly affected the iron content of about $5 \%$ lower than external blending due to the entrainment of ash and other unbeneficed components in the anode carbon. Therefore, considering comprehensively, pellet quality reduced by the external blending was obviously better than the internal blending. It is more reasonable to choose the method of external blending to treat the red mud without additional desulfurizer for solidification and desulfurization.

\subsection{Melting Separation Affected by Iron Content}

Considering the green pellets, since it has the disadvantage of lower iron content and small bulk density, it was uneasy to conduct electricity and heat in the experimental scale furnace. Therefore, pellets need to be briquetted ${ }^{[7]}$. Firstly, no extra flux iron block was charging in the melting process. After melting, the block was relatively loose, and the slag and iron were basically not separated (S1). In fact, it was a mixture of slag and iron. The main reason was that the quantity of molten iron was too small form a big molten bath and the quantity of slag was relatively large. Under laboratory conditions, the slag volume was quite large that made it difficult for slag to float up and separate naturally. Therefore, it was necessary to improve the molten pool conditions.

A pure iron block was successfully obtained with $30 \%$ mass charging of the iron block (S2). The separation effect of slag and iron was good and there was an obvious slag-iron separation interface. The iron block was compact and the slag block was basically compact, which indicated that the slag phase floated more fully during melting process and achieved the purpose of slag-iron separation (Figure 5).

The composition of the molten iron block was shown in Table 8. From the component analysis, the iron content reached $98.85 \%$ and the carbon content is $0.13 \%$. It was actually the composition of steel, that is, molten steel was obtained. In the high metallization rate pellets after direct reduction, it showed that only iron was simple substance, while other components were mainly oxides with high melting point. During melting process, most of iron melted and entered into the molten iron , a 
few numbers of oxides such as Si and Mn were reduced and melted into molten iron by the carbon brought from the pellets, and other oxides basically entered into the slag. The quality of the molten steel was so good that various target steel products can be obtained after controlling the content of S, P and other components through appropriate refining process, thus greatly simplifying the production process from comprehensive utilization of red mud to end products.

Table 8

Main Components of Melted Iron (wt \%)

\begin{tabular}{|lllllll|}
\hline Sample Number & $\mathrm{Fe}$ & $\mathrm{C}$ & $\mathrm{Si}$ & $\mathrm{Mn}$ & $\mathrm{P}$ & $\mathrm{S}$ \\
\hline S2 & 98.85 & 0.13 & 0.58 & 0.04 & 0.027 & 0.26 \\
\hline
\end{tabular}

The composition of the slag after melting and separation was shown in Table 9. The iron content in the slag was less than $3 \%$. It was estimated that the iron recovery rate in sample S2 was $96.5 \%$ which indicated the iron loss was few. A large amount of alkali metal and fluoride originated from raw material have been solidified in the slag, that is, the raw materials were stable and safe after being processed by the pyrotechnic process. In addition, the aluminum compound contained in the slag was as high as about $37 \%$, which had good economic recycling value and can be returned to the alumina extraction process through blending, thus to realize the fully use of everything by self-circulation and zero emission within the enterprise.

Table 9

Main Components of Slag (wt \%)

\begin{tabular}{|lcccccccc|}
\hline Sample Number & $\mathrm{Al}_{2} \mathrm{O}_{3}$ & $\mathrm{SiO}_{2}$ & $\mathrm{TiO} 2$ & $\mathrm{CaO}$ & $\mathrm{Fe}_{2} \mathrm{O}_{3}$ & $\mathrm{MgO}$ & $\mathrm{Na}_{2} \mathrm{O}$ & $\mathrm{F}$ \\
$\mathrm{S} 2$ & 37 & 9.2 & 8.5 & 7.7 & 3.3 & 1.6 & 17 & 13 \\
\hline
\end{tabular}

\section{Conclusion}

1) Through the route of "external heating reduction and melting separation", co-disposal treatment of red mud, waste cathode and anode carbon powder is completely feasible.

2) Through direct reduction with high temperature and external heating, the reduction rate of iron in red mud is high, which could reach more than $95 \%$.

3) The method of external blending was beneficial to the quality of metalized pellets. The pellets had low content of C, S and impurities, and it is unnecessary to add desulfurizer alone.

4) The reduced pellets must operate under the condition of mixed with iron blocks or melted by reserved molten pool.

5) The molten steel can be obtained with high quality such as the iron content is $98.85 \%$, the carbon content is $0.13 \%$ and the iron recovery rate can reach more than $96 \%$.

6) The aluminum compound in slag can reach more than $37 \%$ that can be directly blended into alumina extraction process.

\section{References}

1. GU H N et al. Review on separation, recovery, extraction and comprehensive utilization of iron from red mud [J]. Chemical Industry and Engineering Progress, 37 (9), 3599-3608 (2018).

2. YANG X P, SHAO Z C, ZHANG, C. Comprehensive utilization of red mud resources [J]. Modern Metallurgy, 46 (1), 42-44 (2018). 
3. YANG, J. J. Analysis and application of Harmless treatment spent cathode carbon blocks technology [J]. Light Metals, 66 (1), 38-40 (2014).

4. GAO J J,QI Y H et al. Experience on the combined extraction of iron and alumina from red mud [J].Iron and Steel, 2015 (09):11-16.

5. ZHANG, S. M. et al. Recovery of Iron Minerals from Red Mud by Gas Reduction Roasting and Low Intensity Magnetic Separation [J]. Metal Mine, 52 (6), 179-182 (2018).

6. NING, G. S. et al. Reduction Kinetics of Carbon-bearing Pellets of Red Mud [J]. Nonferrous Metals (Extractive Metallurgy), 68 (1), 24-27 (2017).

7. CHEN W B, GAO, S. et al. Melting-separation for red mud pre-reduced pellets [J]. China Metallurgy, 27 (11), 14-17 (2017).

\section{Figures}

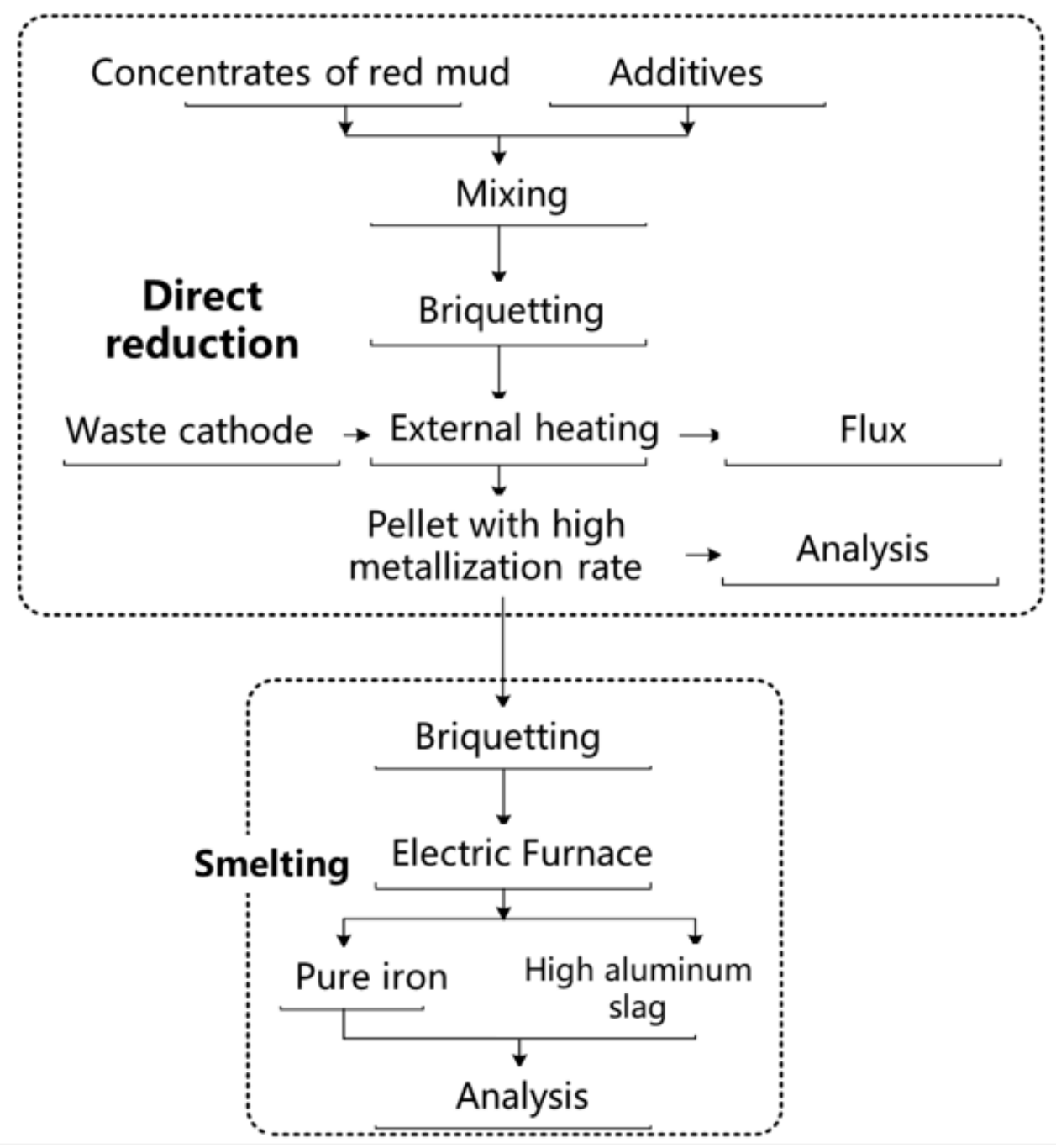

Figure 1

Experimental process route 


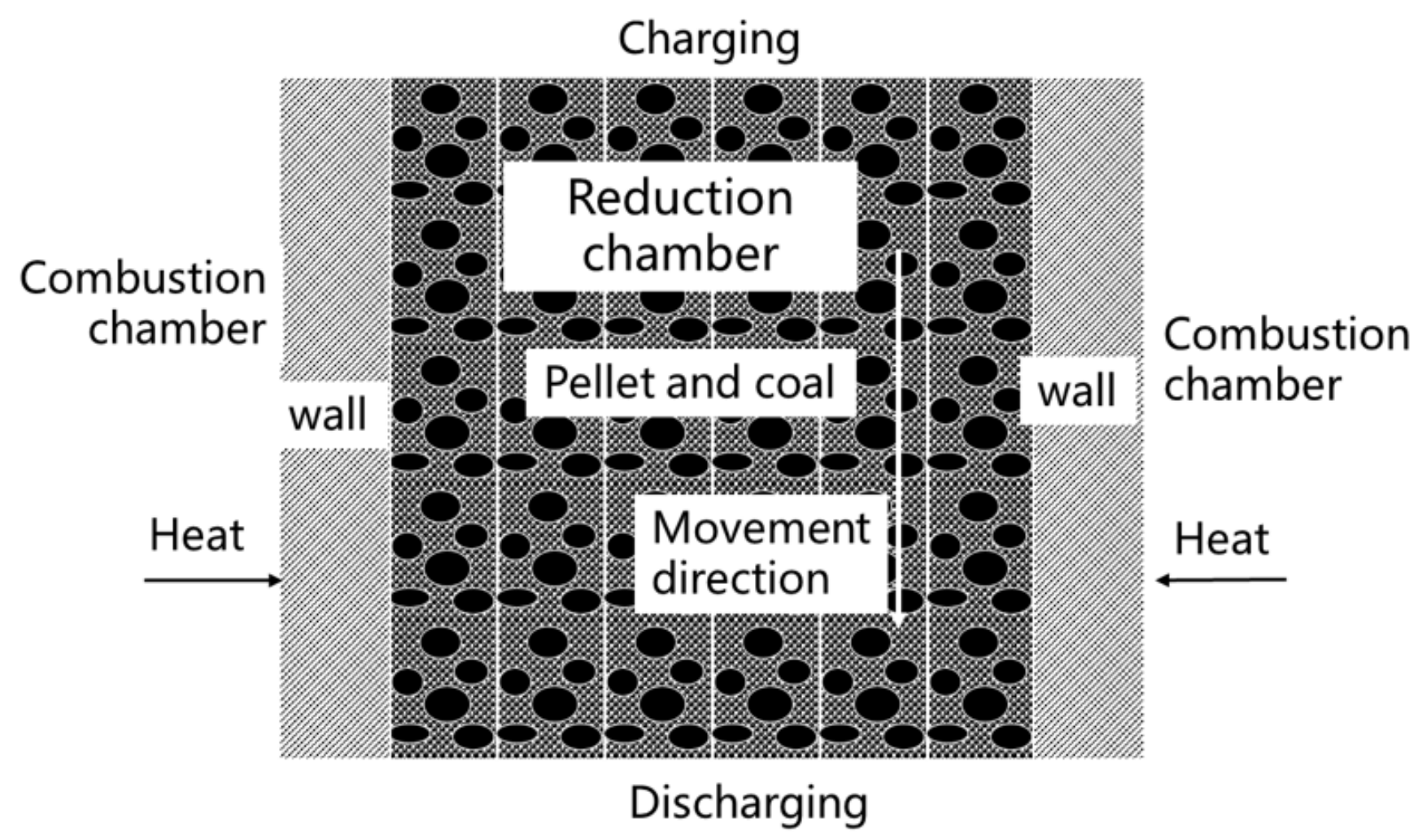

Figure 2

Schematic diagram of external heating

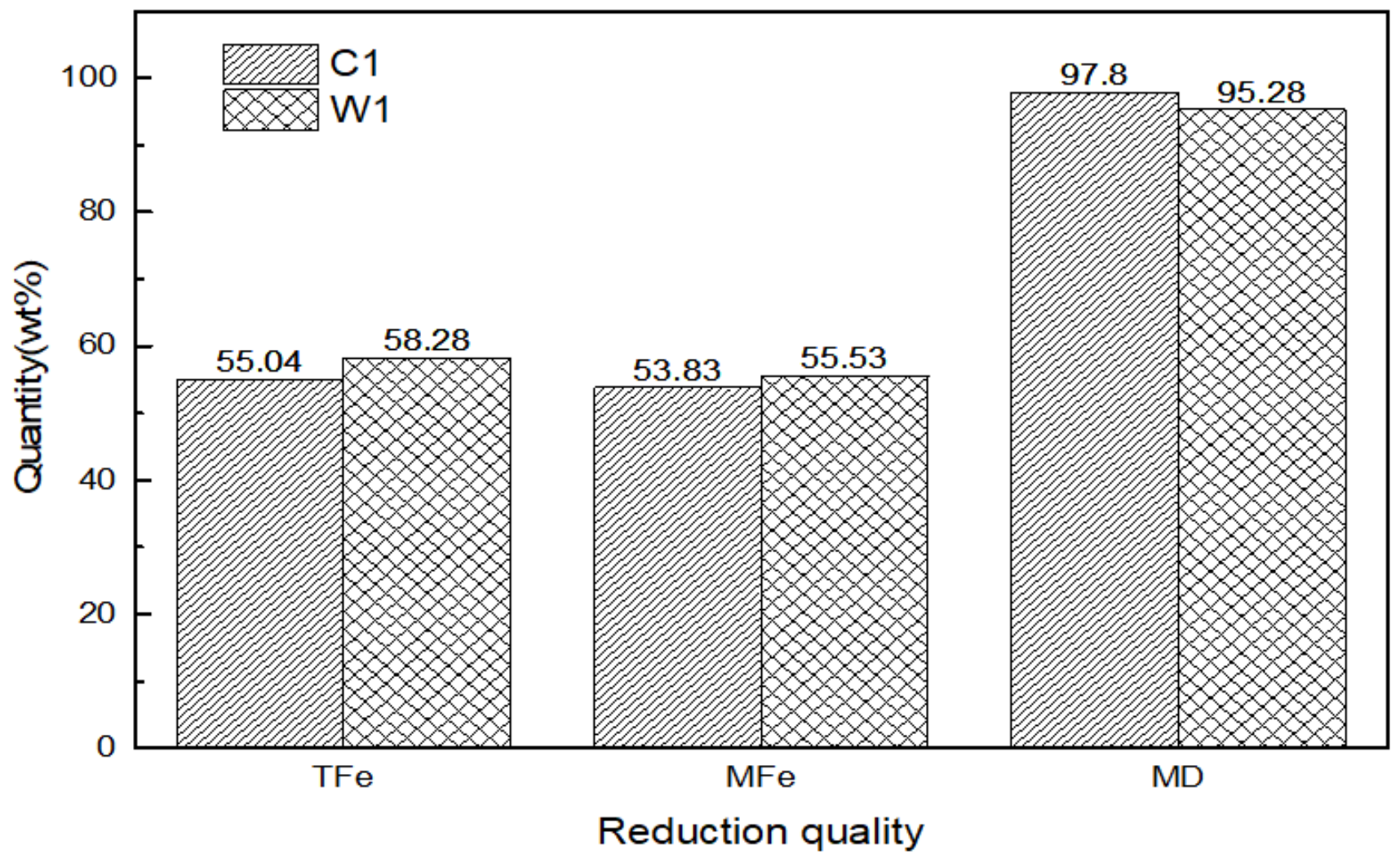

Figure 3 

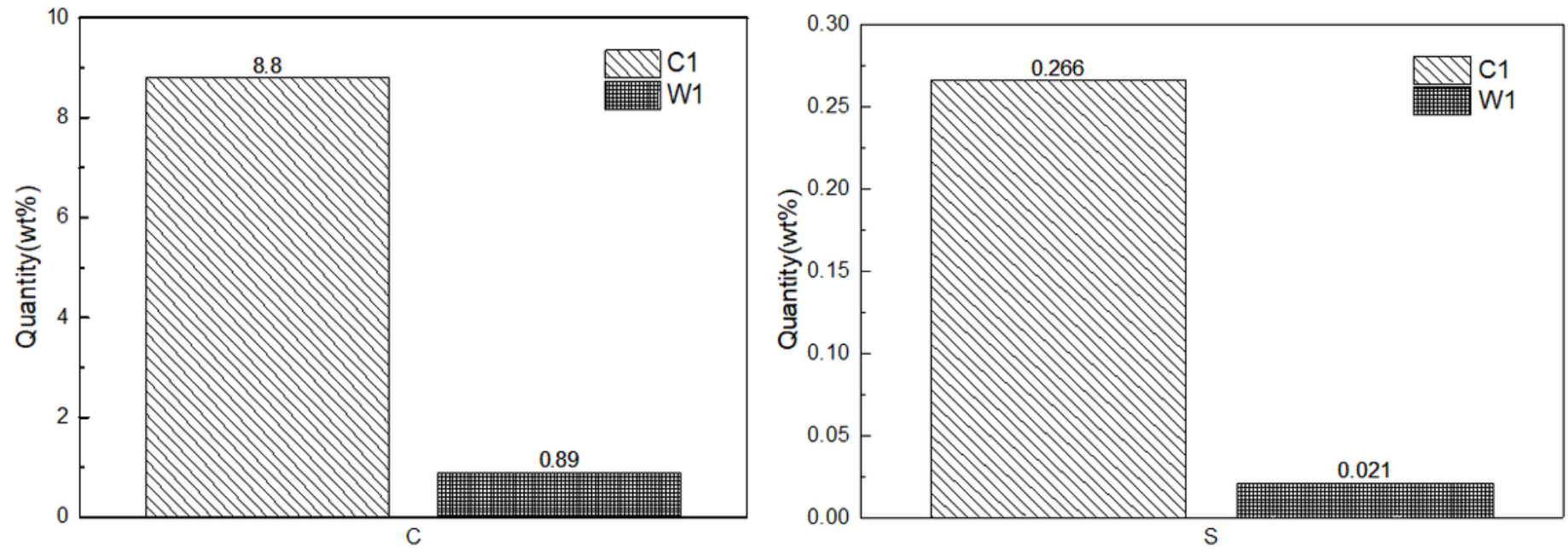

Figure 4

Quality comparison between internal blending carbon and external blending carbon
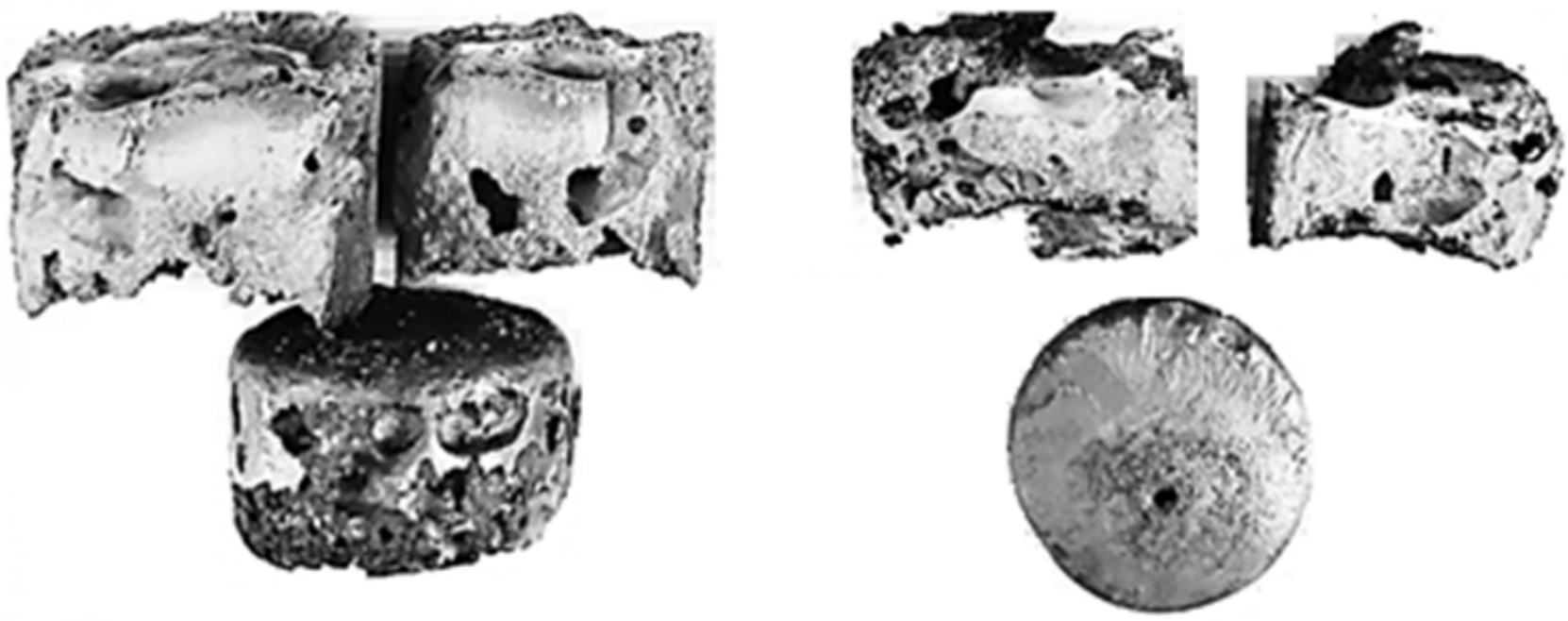

(1) $\mathrm{S} 1(2) \mathrm{S} 2$

Figure 5

Melting and separating products 